\title{
Reforming capital gains taxation of intercorporate share realizations : a law and economics approach from a Nordic perspective
}

DOI 10.1515/ntaxj-2017-0003

Received Mar 12, 2017; accepted Mar 31, 2017

Keywords: taxation, international taxation, features of good tax systems, tax exemption,participation exemption, income, capital, capital gains, corporate reorganizations, group of companies, tax refom, lock-in, accrual tax

\section{Some theoretical and economical aspects of reforming corporate capital gains tax}

\subsection{Challenges of taxing corporate (or other) capital gains}

In this article the authors will make an effort to identify and consider (using a Nordic perspective) the main challenges and reform possibilities of corporate capital gains taxation (specifically the tax rules for intercorporate share alienations) in Europe. The high-level general issue of creating a functional and effective corporate tax system has obviously been discussed frequently during the last years. ${ }^{1}$ The core issue of our article is important from the corporate taxation and economics perspective, but it also triggers the discussion in the area of transactions at a group level. Even though in principle all possible sales (alienations) of different forms of company assets could be considered here, the major idea of our article is to be focused

Anu Torkkeli: Doctor of Economics (2016), Post-doc researcher, Hanken School of Economics, Helsinki; Email: anu.torkkeli@hanken.fi.

Matti Kukkonen: Dr. Iur (Tax Law, 1996), Doctor of Economics (2000), Professor, Head of Department of Commercial Law and Accounting, Hanken School of Economics, Helsinki; Email: matti.kukkonen@hanken.fi.

1 See for example the recent articles by Avi-Yonah (2016) and Kari (2015). on the capital gains tax viewpoint of a seller in a group structure (our basic case: mother company - daughter company; a two-level ownership structure). The possible corporate capital gains tax of intercorporate ${ }^{2}$ alienations of shares is analyzed from the seller company's viewpoint (=tax subject).

Nowadays, the concept of so-called participation exemption is widely used to refer to (possible) tax exemption of intercorporate capital gains within a larger structure of groups of companies. Even though the symmetric tax exemption of intercorporate dividends may be related to tax exemption of intercorporate capital gains, the scope of this article does not cover tax issues of intercorporate dividends ${ }^{3}$. However, some relevant situations for completing the discussion on the corporate capital gains taxation, references are made to double taxation of dividends ${ }^{4}$ and chain taxation ${ }^{5}$. In addition, even though the main focus of this article is not on the tax avoidance aspects ${ }^{6}$, tax avoidance is somewhat discussed because many of the corporate capital gains taxation regulations try to reduce the tax avoidance possibilities.

Taxation of capital gains is not in any level an easy and straightforward subject. It effectively touches many different and various aspects of the determination of the

2 The term intercorporate refers in this article to the share alienations within a larger corporate structure (group of companies). The basic alienation case considers the taxation of mother company selling the shares of a daughter company: can the seller company "use" participation exemption or not? These alienations are sometimes also described as intracorporate sales.

3 See Eicke $(2009,48)$ and Keskitalo $(2012,59-60)$ about the discussion on the terms participation exemption and tax exemption.

4 Double taxation means that profits and payments taxable on the corporate level are also subject to personal income tax at the shareholder level.

5 If the profit would be taxed in several entities before the profit is paid to a natural person, the profit would be taxed many times and that is called chain taxation.

6 Tax avoidance refers to an action taken by the taxpayer to avoid the payment of taxes. For more information, see Tax Procedure Act (TPA) $28 \S$. 
tax. Capital gains taxes are also a significant research topic from the economic efficiency perspective. In Finland and many other European countries corporate sector has been noticed to export capital more and more from abroad.

Corporate income taxation should improve economic efficiency by encouraging entrepreneurship and by being competitive and assessable. Growth of capital flows is one of the key features of globalization. Investments, productivity and income have always also been important topics in the economics related discussions. Increasing the amount of capital is investing. Capital can be considered to be everything that is supporting business to generate profit. Technical progress of the country increases the productivity of capital, and country's output resulting from the investment in the capital depends of the productivity of capital. Income can be considered to be interest of capital value according to the perfect definition of income. On the other hand, corporate capital gains can be considered to correspond to that interest of capital as the value increase of the capital.

Therefore, corporate capital gains taxation is a significant research topic from the whole economics perspective, because findings and future development in that subject matter may considerably boost the dynamics of the international economics. The comparative aspects and results presented in this article are mostly based on the recent results of Anu Torkkeli's doctoral thesis (June 2016, Hanken publications) Structuring Corporate Capital Gains Tax System in the European Union - A Comparative Finnish Perspective $^{7}$.

\subsection{The various aspects of taxing capital gain: a short summary}

Based on Simontacchi $(2007,137,142)$ capital gains taxation has the nature of income taxation, because capital gains are considered as an increase in the value of the asset accrued during certain period of time. Even though there is inconsistency in the definition of capital gains between

7 Anu Torkkeli, Publications of Hanken School of Economics, Nr 296, Helsinki 2016. The academic opponent of Torkkeli's thesis was professor Mattias Dahlberg from Uppsala. The co-author of this NTJ-article, professor Matti Kukkonen has worked as Anu Torkkeli's academic supervisor at Hanken. Professor Kukkonen has earlier published a doctoral thesis about capital gains both in tax law (Income Tax Issues of A Company Sale (in Finnish), Helsinki, Lakimiesliiton kustannus, 1994) and economics (Capital Gains Taxation and realization behaviour: evidence from Finnish panel data, HSE A 168, 2000). countries, there are certain issues that are generally considered in capital gains taxation.

Different theories of income have formulated the basis for corporate income taxation and thus also for the corporate capital gains taxation over the years. ${ }^{8}$ It depends on the definition of income and the tax regime of capital gains, whether the definition of capital gains is needed in the tax law. If all the capital gains are taxed as normal business income, no special rules need to be defined in the tax law. Capital gain arises because of the value increases, and it can either exist in an unrealized or realized form. Capital gains are calculated as a difference between the consideration received and the cost of the asset, and therefore the capital gain describes the change in value between the end and beginning of the period under consideration.

The discussion on whether to tax only realized or also unrealized capital gains have been colorful. Even though majority of the countries are currently applying realization principle (taxing only realized capital gains), they have noticed the weaknesses of that because they have implemented special rules for special situations. The biggest worry related to using capital gains taxation on the unrealized gains is that companies would not have money to pay taxes when gains have not yet been realized, and that that taxing methodology will increase significantly administrative work.

The theoretical (and practical) major problem issues related to the taxation of changes in value can be listed as follows:

- The extent of the definition of income: whether changes in value are taxable

- Spreading of taxation of changes in value: whether changes in value are taxed based on accrual or realization

- Taxation method of inflation component of change in value: whether taxation is applied to nominal or real change in value

- Tax systems of changes in value: independent taxation, proportional taxation or partial or complete progression

- The effect of ownership time to the tax rate

- Tax treatment of undistributed (distributed) profit of a limited liability company: whether undistributed profit (hidden increase in value of shares) is under double taxation

8 For the issues related to the ambiguous concept of (taxable) income see the interesting doctoral dissertations (IBFD series) published by Holmes (2001) and Laukkanen (2007). See also Kavelaars (2005). 
- Tax neutrality of tax treatment of different types of capital income and taxation of changes in value of different taxpayers (individuals/corporate bodies)

- Deductibility of loss: deduction forward or backwards, limitations.

\subsection{Capital gains tax issues from law and economics perspective: the realization principle and one example of accrual tax rule}

As Simontacchi (2007, 131-132) discusses, in most countries the income tax is operated on a realization basis, which means that income is only taxed when realized. Capital gains are taxed not earlier than when the alienation is realized. There are some exceptions to this rule of thumb, for example revaluation of assets is taxed based on the accrual principle. ${ }^{9}$ It has been argued (Simontacchi $(2007,131-132)$; OECD $(2006,104))$ that capital gains are not normally taxed based on the accrued tax, because it would be difficult to get the correct value of property at a certain moment and it may cause cash deficiency to the taxpayer. Periodic valuation of assets may imply high tax compliance and administration costs where there is no obvious market to establish a fair market value, as could be the case for certain intangible property or claims on such property. It has been concluded (Bankman et al. $(2005,131))$ that realization does not have a single, allencompassing definition. In some cases it may be obvious when the realization has occurred. For example, a sale of property for cash is obviously a realization event. In other cases, the time of realization is less clear. The realization event should occur before taking the gain or loss into consideration according to Evans $(1992,897)$ and Laukkanen $(2007,101)$.

Bankman et al. (2005, 131), and Mirza and Holt (2011, 115-116) comment that the recognized gains and losses are taken into account, for purposes of computing the taxpayer's gross income, only to the extent that they are also recognized. An item of property, plant and equipment satisfying the recognition criteria should be recognized initially at its cost. The cost of an asset is measured at the cash price of the date of acquisition. Capital gains are considered to be realized in the alienation, and ownership transfers in the alienation. As Kavelaars $(2005,127)$ and Laukkanen $(2007,100)$ discuss capital gains cannot be taxed be-

9 For more discussion on the accrual principle, see Kavelaars (2005). fore the realization, because income is contingent, the taxable amount cannot be defined accurately, and taxation should not happen before income is available for investments with an exact amount. As Laukkanen $(2007,101)$, Simons (1938???, 87), and Simontacchi $(2007,132)$ state there are such alienations, however, in which ownership is not transferred. Most of these alienations have specific features, or they do not occur very often.

The total gain of an investment is the sum of running yield, unrealized change in value and realized change in value. Taxable income is however the amount that is defined to be taxed. Often only realized change in value is taxed. Generally realization has meant selling or change of property. Applying realization principle has been often seen as a practical compulsion due to issues related to valuation of property and liquidity. ${ }^{10}$ This principle has also considered as a political reality and necessity. There are also philosophical and ideological viewpoints on that what is considered as income. Applying realization principle is related to the acceptance of the society for that principle. For example, the realization event as the basis for taxation can be justified as the best solution, because it corresponds to the definition of income for individuals. Unrealized increase in value is considered uncertain. ${ }^{11}$ Knuutinen $(2009,90)$ concludes that the concept of realization of investment instrument or other property item can be reviewed from the viewpoint of liquidity, exclusion of risk, and measurability. In a conventional alienation situation the realization meets all those three requirements. Those transactions, which do not meet all those three requirements, are problematic. In those cases an evaluation is needed, whether realization has taken place from taxation point of view or not.

The liquidity requirement of the concept of realization has been met once property has been moved to money. In this case the taxpayer's ability to pay tax increases, when the paying ability is measured in cash. If realization would be analyzed only from this perspective changes from one fund to another inside a fund company would not be considered as a taxable transaction. Because this anyhow leads into taxation of capital gains, the improvement of the taxpayer's liquidity position has not been as a necessary requirement for realization. If the taxpayer borrows money from a bank with the same amount as money invested to the bank, this is not considered as realization. Therefore as Knuutinen (2009, 90-91) and Melz (1986, 66)

10 Schenk (2004b, 374-377). 11 Chorvat (2003, 75), Rosenberg (1988, 371), and Schenk (2004a, 377-382). 
conclude, the improvement of the taxpayer's liquidity position is not an adequate requirement for realization.

From the perspective of risk exposure, realization means closing the risk exposure of the position. Realization principle is often justified by the fact that the risk of the investment is permanently removed and income becomes certain in connection with the realization. Normally the sale of the investment instrument makes sure that the variation of the value in the investment instrument does not anymore affect the financial position of the taxpayer. Realization principle is two-way in that it can be either favorable or unfavorable to the taxpayer depending on the case in question. The taxpayer tries to avoid taxation in a situation, in which tax burden would increase, and tries to activate taxation when realization would lead into deductibility of loss. An investor can eliminate the risk related to the investment object with a hedging instrument without a realization event. Also, a realization event can be simulated with hedging instruments without tax consequences. ${ }^{12}$ As a rule, changes in the economic tax exposure do not have significance for taxation. The realization event should be as per the definition of private law. On the other hand, the investor can alienate an instrument based on the private law, but at the same time synthetically create a corresponding position and still stay as the economic and risk owner. An alienation event defined in the private law generally is enough to trigger taxation, although the economic risk position would not have changed. Therefore as Knuutinen (2009, 91-92) concludes, the change of the taxpayer's risk position is neither adequate nor sufficient requirement. ${ }^{13}$

The measurability viewpoint in regard of realization has the focus on valuing and calculating income. As Holmes $(2001,113)$ states often realization is seen to make it possible to define objectively and accurately enough the amount of income received from the investment. Knuutinen $(2009,92)$ comments that the chance for measurability cannot alone signify realization. The viewpoint of valuation and computability is valuable for example in different exchange situations, in which the liquidity position of the taxpayer is not changing and changes in risk position are marginal. Based on Ault and Arnold $(2004,194)$ and Bittker (1981, 5-16-5-17) economically realization means changes in the taxpayer's liquidity and risk position. Liquidity, exclusion of risk, and measurability requirements are significant when analyzing realization in taxation, be-

12 Goldberg and Watson (1996, 62-67); Paul (1996, 3); Weisbach (1997, 495-506).

13 See also Paul (1996, 21). cause in taxation realization is analyzed as a formal, private law related transaction rather than as an economic transaction. The distinction between owning and alienating property is formal and dependent on definitions. It is important for the functionality of the tax system that how realization has been defined in the tax rules. ${ }^{14}$

Based on the paying ability of tax and horizontal justice, the ultimate purpose in measuring the amount of income is for the basis of the fair division of the tax burden. When applying the realization principle, the amount of income is often measured in a wrong way compared to the economic accrual of income. Based on Knuutinen (2009, 93) that is because economically income can be considered to be earned as an asset appreciates, not when it is sold. ${ }^{15}$ Bittker (1974???, 3) and Knuutinen $(2009,93)$ conclude that the tax system becomes more complex, when the concept of realization requires many rules on defining it and those preventing from exploiting $\mathrm{it}^{16}$. As stated by Holmes $(2005,175-180)$ and Pechman $(1987,118)$ even though realization has the biggest significance in the periodicity of income, it also has a role in questions related to the scope and allocation of income. For example, in death situations income could be left without realization, which is one example of the lock-in situations..$^{17}$ Application of the realization principle is one of the factors that are triggering most tensions between the form and content. In the United States' tax policy the realization requirement has been seen as the linchpin of the tax policy. ${ }^{18}$ Laukkanen $(2007,102)$ argues that in the United States tax deferrals and artificial losses have generated anti-abuse provisions for the tax law ${ }^{19}$. Also tax planning and tax avoidance exist most in situations, in which tensions between the form and content are biggest. Brooks and Head $(1997,61)$ and Knuutinen $(2009,93)$ state that tensions between the definition of capital gains and the Haig-Simons' concept of income have been the most significant reason for the players of the tax planning and tax avoidance to operate especially in the area of capital gains taxation. In this area of taxation the term tax avoidance has been most in use. ${ }^{20}$

14 See also Paul (1996, 50); Powell (1922, 376); Rosenberg (1988, 383); Simons $(1955,84)$.

15 See also Halperin (1998, 494); Hasen (2004, 400); Land (1996, 48); Potter (1999, 879); Rosenberg (1988, 380, 494).

16 See also Halperin $(1998,498)$

17 See also Poterba (1987, 157); Shaviro (1992, 66); Shuldiner (1993, 559). For more details on the lock-in effect, see Kukkonen (2000).

18 Guerin (1985, 907).

19 See also Evans $(1992,897)$.

20 See also Staveley $(2005,609)$. 
In the realization principle the taxpayer may utilize the right to decide her- or himself about the alienation actions and on their timing. The taxpayer can use the options to realize or not to realize depending on the tax impacts. Relating taxation to such transactions that the taxpayer can decide her- or himself are raising questions on justice. Tax law cannot regulate these decisions for the taxpayer. Applying formal realization events may also lead taxpayers to realize such transactions that they would not carry out without those formal tax rules. This makes taxpayers to approach the tax avoidance situations. In addition to justice, another aspect to consider is efficiency when using the realization principle. Immediate efficiency losses are arisen because of the unnecessary transactions done due to tax avoidance and related costs. Realization principle has also been considered to affect different efficiency issues because of its effect on the decisions of investors. One of those efficiency effects is the lock-in effect. Kukkonen $(2000,154-161)$ comments that investors are unwilling to sell such shares that include a lot of accrued gain, and the realization principle can help investors to avoid the taxation. ${ }^{21}$ The lower tax rate has been justified for capital gains because of the lock-in effect. But lower tax rate may trigger other efficiency issues and increase items disturbing justice, even though the lock-in effect may be reduced. ${ }^{22}$ Realization principle fulfills the requirement of legal certainty, but it dismisses justice and efficiency as Knuutinen $(2009,95)$ states. That principle can also been seen to make investing riskier, increase the complexity of tax law and add tensions to tax systems. Justice issues may arise vertically so that a wealthy investor has more options than a less wealthy investor. Justice can also arise horizontally by favoring capital income over earned income. ${ }^{23}$

The current EU-level harmonization of some corporate tax situations leads in effect to accrual taxation of capital appreciation. One clear example of this trend is the most recent anti-tax-avoidance directive (ATAD (EU) 2016/1164) which will cover all taxpayers that are subject to corporate tax in a member states, including subsidiaries of companies based in third countries. It lays down anti-taxavoidance rules for situations that may arise in five specific fields:

1. Interest limitation rules.

2. Exit taxation rules, to prevent tax base erosion in the state of origin. Corporate taxpayers may try to reduce their tax bills by moving their tax residence and/or assets, merely for aggressive tax planning purposes.

3. General anti-abuse rule.

4. Controlled foreign company (CFC) rules.

5. Rules on hybrid mismatches.

Based on these rules a tax is levied on the transfer of assets if:

1. Assets are transferred from the taxpayer's head office to its permanent establishment (PE) in another Member State or third country in so far as the Member State of the head office no longer has the right to tax the transferred assets due to the transfer;

2. Assets are transferred from a PE in a Member State to the head office or another PE in another Member State or in a third country in so far as the Member State of the PE no longer has the right to tax the transferred assets due to the transfer;

3. The tax residence is transferred to another Member State or to a third country, but not with respect to assets that remain effectively connected with a PE in the first Member State;

4. A business carried out by a PE is transferred out of a Member State to another Member State or third country in so far as the Member State of the PE no longer has the right to tax the transferred assets due to the transfer.

The taxable base is formed by the difference between market value and value for tax purposes at the time of exit of the assets concerned. This means in effect an accrual tax on capital appreciation (gain) which was discussed (from a more theoretical perspective) in detail earlier in this article (accrual or realization based tax?). If assets are transferred to another Member State, those Member States are obliged to allow taxpayers to value the assets at market value. In such cases taxpayers also have the right to defer tax claims arising from exit taxation by paying in installments for five years. This means that there is a postponement possibility for the actual payment of capital gains tax. If a taxpayer chooses to defer a tax claim, interest may be charged and, if there is an actual risk of non-recovery, securities may be demanded by the Member State involved. EU member States should apply this provision by January 1, 2020.

21 See also Blum (1957, 256-259); Cunningham and Schenk (1993, 344-350).

22 Kornhauser (1985, 869); Land (1996, 50).

23 See also Hasen (2004, 398-399); Land (1996, 48-49). 
Table 1: Comparison of the corporate capital gains taxation models in the European Union countries (2014)

\begin{tabular}{|c|c|c|c|c|c|c|}
\hline \multirow[t]{15}{*}{$\begin{array}{l}\text { Capital } \\
\text { gains tax } \\
\text { exemption }\end{array}$} & $\begin{array}{l}\text { Full } \\
\text { exemption } \\
\text { on capital } \\
\text { gains on } \\
\text { shares }\end{array}$ & $\begin{array}{l}\text { Partial } \\
\text { exemption } \\
\text { on capital } \\
\text { gains on } \\
\text { shares }\end{array}$ & $\begin{array}{l}\text { Full exemption of } \\
\text { capital gains on } \\
\text { some other assets } \\
\text { in addition to } \\
\text { shares }\end{array}$ & $\begin{array}{l}\text { Partial exemption } \\
\text { on capital gains on } \\
\text { some shares and } \\
\text { some other assets } \\
\text { in addition to shares }\end{array}$ & $\begin{array}{l}\text { Full exemption } \\
\text { on capital gains } \\
\text { on other assets } \\
\text { than shares }\end{array}$ & $\begin{array}{l}\text { No } \\
\text { corporate } \\
\text { capital } \\
\text { gains tax } \\
\text { exemption }\end{array}$ \\
\hline & Austria & Belgium & Cyprus & Portugal & Poland & Croatia \\
\hline & Bulgaria & France & Estonia & & & Greece \\
\hline & Czech & Italy & Hungary & & & Slovakia \\
\hline & Republic & & & & & \\
\hline & Germany & Slovenia & Spain & & & \\
\hline & Ireland & & & & & \\
\hline & Latvia & & & & & \\
\hline & Lithuania & & & & & \\
\hline & Luxembourg & & & & & \\
\hline & Malta & & & & & \\
\hline & Netherlands & & & & & \\
\hline & Romania & & & & & \\
\hline & United & & & & & \\
\hline & Kingdom & & & & & \\
\hline
\end{tabular}

\section{Comparison of the current European corporate capital gains tax models}

\subsection{A common playground?}

The international viewpoint to the corporate capital gains taxation (tax systems of intercorporate share alienations) can provide some visibility to how the corporate capital gains taxation system should be developed in the future and what a future corporate capital gains taxation model could be. Economic integration takes place most efficiently between such countries, of which the cultural, linguistic and social background is similar and which are located near to each other. The common Nordic market area enhances the diversification of the production and export and strengthens the competitiveness of the companies of the area also outside the area. The capital gains tax system perspective is an important research focus because it would be valuable to the society to re-focus on the innovation at the EU level and to re-allocate capital resources across firms and innovations systems. This means that in the ideal situation the results of the studies among the area of the capital gains taxation would serve as a trigger for EU-wide development of the economic innovations. Even though the main focus is in the system level approach, the current corporate capital gains taxation models in the indi- vidual countries have played a significant role in the capital gains taxation development so far, and it may not be possible to introduce a huge harmonization activity to get rid of all features developed in the country-specific corporate income tax regulations. The tax exemption principles of the European Union countries can be split to some key principles or models (see Table 1).

Corporate capital gains are taxed based on the net distributions in Estonia (double taxation avoided because only taxed at corporate level). In Germany 95 percent of the capital gains from the sale of shares of resident and nonresident companies are fully exempt regardless of the level of shareholding, length of the holding period or number of voting rights. In Netherlands the minimum ownership share is defined based on the paid-in capital, and there are additional requirements based on wealth and the level of taxation. United Kingdom's corporate capital gains taxation is a combination of the source and residence based taxation, and tax exemption applies to substantial shareholdings in trading companies.

The future focus could have at least a couple of interesting considerations. Tax rate harmonization could stay at a reasonable level, which will not remove fully the natural life cycle of companies seeking for the most competitive location for the business. The economic impact of different corporate capital gains taxation systems and corporate capital gains taxation renewals could be investigated further. Corporate capital gains taxation could also be devel- 
Table 2: Comparison of the corporate capital gains taxation models in the Nordic countries (2016)

\begin{tabular}{l|lllll}
\hline & Denmark & Finland & Iceland & Norway & Sweden \\
\hline Tax rate & 22 & 20 & 20 & 25 & 22 \\
$\begin{array}{l}\text { Capital gains tax treatment } \\
\text { in normal case }\end{array}$ & Ordinary & Ordinary & Ordinary & Ordinary & Ordinary \\
Capital gains tax exemption & income & income & income & income & income \\
& $\begin{array}{l}\text { Sale of } \\
\text { subsidiary and } \\
\text { group shares }\end{array}$ & Sale of shares & Sale of shares & Sale of shares & $\begin{array}{l}\text { Sale of } \\
\text { business- } \\
\text { related shares }\end{array}$ \\
\hline
\end{tabular}

oped so that it supports the innovations and development type of work. The tax exemption principles of the Nordic countries can be split to a couple of key principles (see Table 2). ${ }^{24}$

Common feature of the development of the corporate capital gains taxation in the Nordic countries has been lowering the corporate income tax rate to follow the international corporate income taxation trend of the last years. Flat proportional tax rate is used as the corporate capital gains tax rate. Rates could be still aligned between countries in the future.

Requirements for the subject and object companies for the tax exemption have been defined in the corporate capital gains tax regulations of the Nordic countries. Sweden has paid attention to tax avoidance by creating special taxation rule for shell companies as object companies and trading companies as subject or object. Norway was using a percentage limit for tax-exempt items in 2008-2011. Denmark has created special regulations regarding the holding company structures as alienator to avoid tax avoidance situations. Key differences of the Nordic corporate capital gains taxation models are in the regulations created for tax avoidance and the regulations created to identify a share ownership with business relationship.

The various identification requirements complicate the interpretation of the exemption rules. In some cases there is only a thin line between normal tax exemption and tax avoidance. As an example of this ambiquity see below for a published Finnish tax case from the Supreme Administrative Court concerning the business nature of a two-level corporate ownership structure between an investment company and business company. This case reflects the current tax law interpretation of Finnish participation exemption rule.

24 For more details for these countries, see Torkkeli (2016, chapter 5).

\section{Example: The Finnish participation exemption rule: Business Income Tax Act 6 b $\S$}

The Supreme Administrative Court Decision (KHO) 2012:73 (for an opposite interpretation see KHO 2012:74) indicates that the transfer of assets so that the business relationship remains between the parent company (the old business company) and the new company continuing the business means that the Tax Procedure Act 28 \& cannot be applied and the Business income Tax Act $6 \mathrm{~b}$ is applied even though the mother company (seller) is effectively "only" a holding company. ${ }^{25} \mathrm{~A}$ Oy had been involved in establishing B Oy in 1998, after which A Oy sold its business to B Oy. A Oy had gained based on the participation agreement done in the connection of the establishment of B Oy royalty income up to 236000 euro until the year 2006. B Oy had operated within premises which A Oy had acquired and renewed for that purpose and rented to B Oy. A Oy had rented apartments to the employees of $\mathrm{B} O \mathrm{Oy}$ and in 20032006 cars to the use of B Oy. B Oy had started the business on August 11998 partly with the machinery and equipment of A Oy. A Oy had alienated its production machinery and equipment to the use of $\mathrm{B} \mathrm{Oy}$ without a consideration for the first three years. In December 2001 B Oy was committed to pay to $\mathrm{A} O \mathrm{Oy}$ on the production machinery and equipment a total compensation of 410000 Finnish markka. A Oy had granted loans to B Oy and guaranteed loans of B Oy. The only shareholder and member of the board of $A$ Oy had been working as a chief executive officer and member of B Oy during the time period between the establishment of B Oy and the alienation of shares in 2006. When the above-stated items were taken into account as a whole, A Oy was considered as a company carrying out business and the shares of $\mathrm{B} O \mathrm{y}$ belonged to the fixed assets of $\mathrm{A} O \mathrm{y}$ based on the operational and administrative relationship described above.

25 See also Kukkonen and Walden (2015, 427-429); Torkkeli (2016, 191-192). 


\section{Tax reform: an advanced model for taxing intercorporate capital gains}

\subsection{General remarks}

In the current economic situation, there are actually several significant options to renew the corporate income taxation in Finland, all Nordic countries and more generally within the EU. To increase the competitive edge of the EU in the world economy, the member states should consider a general-level tax harmonization between the countries. That could boost the latent entrepreneurs or ideas for enterprises to implement new business activities in other European Union countries. However, the actual (real) tax harmonization in the European Union requires skillful tax and public finance specialists to negotiate the common future outlook and also to build the needed authorities not only to administer the European Union -wide corporate taxation system but also to manage that change so that the subsidiarity of the member states is not neglected. It is yet difficult to assume that a common tax base (see below) could be a real possibility in the near future, at least not for the SMEs.

\section{Common corporate tax base?: The most recent proposals}

The newest EU-level proposals on a Common Corporate Tax Base (ССТB) and a Common Consolidated Corporate Tax Base (СССВ) were published on 25 October 2016 (Corporate Tax Reform Package). With these proposals, the European Commission intends to proceed in a two stage approach, first aiming at an introduction of CCTB, and when that would be achieved, the legislative process relating to the introduction of a СССТВ could be started. The re-launch follows the lack of progress in the Council concerning the 2011 proposal (COM(2011) 121). The 2011 proposal was withdrawn when the 2016 ССТВ and СССТВ proposals were published.

The current CCTB provides for the determination of a single set of rules for the calculation of the corporate tax base. Companies operating across borders in the EU would therefore no longer have to deal with 28 different set of national rules when calculating their taxable profits. Contrary to the 2011 CССТВ proposal, the latest proposal is mandatory for groups of companies beyond a certain size, namely those with a consolidated turnover exceeding EUR 750 million. Companies that remain under this threshold would be given the possibility to opt in to the system. Under CCTB, companies will still have to file a separate calculation and tax return in all Members States where they have a taxable presence.

The ССТВ proposal includes tax exemption for corporate dividends and also for capital gains (with minimum of twelve months of ownership time and $10 \%$ investment level). The proposal would also introduce an extra deduction for research and development costs. For R\&D expenditure up to EUR 20000 000, taxpayers will be entitled to a yearly extra super-deduction of 50\% (above $25 \%$ ). Small starting companies would be granted an enhanced deduction of an additional $100 \%$ for R\&D expenditure.The proposal addresses also the problem of debt receiving a more favourable tax treatment than direct capital investment. This proposal concerns the corporate tax base and it is not meant to harmonise the various national corporate tax rates.

One possible and a very major tax reform change regarding company taxation could at least in principle be a total focus shift from the company (firm) level tax to the owner-investor level tax (Example: the Estonian tax system). This may not be the most realistic way. If the company tax is effectively or formally reduced to zero, there is no lock-in incentive for capital asset owners and there is no effective or nominal capital gains tax. This kind of focus change would also abolish the legal interpretation problems of participation exemption systems. The dividends and capital gains (at least regarding alienations within groups of companies) are already tax-exempt in most of cases considering the realizations of limited companies. At the same time the overall levels of company taxes have been going down. The tax rate is "only" $12,5 \%$ in Ireland, even in Finland the corporations pay not more than 20\% as maximum tax.

Comprehensive business income tax (CBIT) model has been under the most serious consideration for future $\mathrm{Eu}$ ropean level tax model. In that model, the uniform taxation of the different forms of financing is implemented by eliminating the interest deduction of the debt. In CBIT model, double taxation would exist and taxation would not be neutral. However, Hjerppe et al. $(2003,86))$ argue that from the fiscal perspective, the comprehensive business income model would be more profitable than the alternatives, the economic ACE model and the cash flow tax model. ${ }^{26}$ Mooij and Devereux (2008) comment that CBIT can be accompanied by an abolition of personal taxes on capital. Therefore, it avoids double taxation of some sorts of capital income - such as dividends - and broadens the base to currently exempt types of capital income - such as that earned by institutional investors. A disadvantage of the CBIT model is that it raises the cost of capital on debt-financed investments. Fewer investment projects will be profitable at the margin and thus investment declines. This effect is opposite to the ACE model. The broadening of the base under CBIT will raise corporate tax revenue. If the overall tax revenue is to be maintained, the CBIT model allows for a lower corporate tax rate. This de-

26 See also Myrsky $(2014,96)$. 
creases the cost of capital on equity-financed investments and may attract mobile economic rents or paper profits of multinationals. This is opposite from the ACE model: the CBIT model is shifting the tax burden away from rents towards the marginal investment return. If mobile rents, credit constraints and multinational profit shifting are important relative to marginal investment decisions, then the CBIT could be attractive.

You can easily argue that the corporate capital gains tax system should be developed paying attention to the functionality and freedom of the market. Especially division to the sources of income is currently considered hampering the operational and structural structures of companies. Keskitalo (2012) has considered in his dissertation study that Sweden's corporate capital gains taxation model is flexible and vast, and that could be used also as a starting point for renewals in Finland. At the same time the changes to the tax base should be analyzed. It would be worthwhile to exclude the distribution of profits from the tax base. This would mean that dividends, capital gains and other profit distributions would be tax-exempt regardless of their source state.

Keskitalo's idea is that in this way the tax exemption would become applicable without the provisions on ownership time, ownership share and asset type. Correspondingly, capital losses, dissolution losses and writeoffs could not affect the corporate tax base directly or indirectly. Keskitalo $(2012,925)$ argues that it should also be investigated, whether it would be possible to allocate the corporate tax to that part of the taxable business income that the company distributes as profits to shareholders. This basic idea is actually well in line with the current Estonian corporate capital gains taxation model.

\subsection{A new combined Nordic model?}

Neither the total harmonization or the total abolition of corporate tax should probably be a dictating force in the short term at least. The main focus could instead be in setting up cross-border bodies for investigating the corporate capital gains taxation systems, searching for best practices, investigating the impacts of the corporate capital gains taxation systems to economics and sharing knowledge and information to EU member states on other EU member states. This would improve the quality of the possible changes in the future corporate capital gains taxation systems. Even Constitution Act supports the approach when interpreting a wider context - that the corporate income taxation is set out so that EU member states are in the equal position with each other based on the corporate income taxation system. It is also possible that in the future harmonization of the corporate income taxation between the EU member states could be made easier with a multilateral agreement, which would make implementing of changes quicker.

The somewhat more limited tax harmonization option would be to renew, as a start, the corporate tax systems and taxation of corporate gains through the harmonization of tax rates or, more specifically tax exemptions between the Nordic (dual income tax) countries. Taxation of corporate capital gains is one challenge that the Nordic and European countries could start cooperating more to enhance the entrepreneurship, to increase the overall economic activity and to speed up the dynamics of the economy. Harmonization discussions have here two important aspects. First, cooperation in the area of corporate capital gains taxation inside the Nordic countries is a necessity, because all the Nordic countries are not part of the European Union. Second, the Nordic countries could lead the way to building cross-border corporate capital gains taxation development bodies. After having shown some results, the whole European Union could start seeing the value of that kind of renewal and may start building similar kind of bodies inside the European Union.

This would also mean that a more modern and multidisciplinary approach would be used for the corporate tax reforms in Europe. More cooperation and organizational bodies working towards the common targets of a good corporate income tax system is needed both at the level of the Nordic countries and European Union. The future corporate income taxation should be challenged with new crossscientific perspectives. In addition, the focus should be in the cross-border taxation issues, because in the current globalizing world there is no way to avoid situations, in which there are group companies in the Nordic countries and European Union but also in the third countries. To ease the companies to allocate their time as much as possible to drive the business itself in an international arena instead of paying much money and spending a lot of time for administrative tax questions, the corporate income taxation should be as simple as possible.

According to our view, a functional and realistic corporate capital gains tax system for intercorporate capital gains (share alienations) can be created by combining the current features of the Danish, Dutch, and UK corporate capital gains taxation system (see the Figure 1 above). More focus should be allocated on the interface between the group taxation overall, group structures and corporate capital gains. The current corporate capital gains taxation systems in the Nordic countries and in the European Union have been mostly prepared purely from the taxation point 


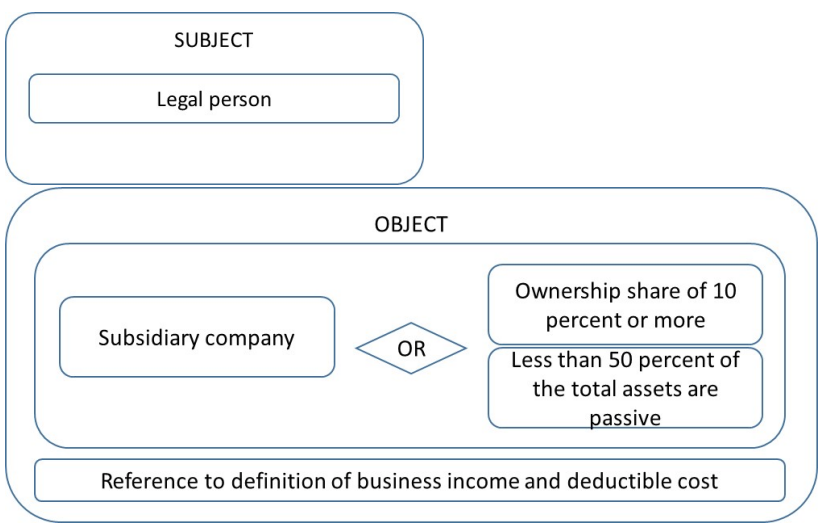

Figure 1: A possible realistic Nordic model for taxing intercorporate capital gains

of view except for the flow-through approach that has been applied in a couple of countries. A new corporate capital gains tax system should utilize more efficiency and simplicity as the features of a good taxation system. Corporate capital gains taxation system should not cause too much administrative work for tax authorities, and at the same time the tax regulations should be simply understandable and usable for companies.

Denmark and United Kingdom have clear object company requirements with ownership share and substantial shareholding that could be used in a new future corporate capital gains taxation system. Netherlands have developed tests, with which companies can test, whether the ownership share in an object company are businessrelated. By combining the provisions for the object company applied in Denmark, Netherlands, and United Kingdom, it would be possible to decide, whether the shareholding in an object company is substantial and businessrelated. In summary, defining a future corporate capital gains taxation system would require renewal not only in the creation phase of the new system by setting up new cross-border bodies and combining multidiscipline knowledge but also in the implementation phase by defining the regulations so that they include enough practicalities for following the regulations as well as linkages between different subject matters or scientific areas. In the future model it would be reasonable to clearly describe the corporate capital income taxation model as a wholeness and then make the needed references to the generic corporate capital income tax regulations inside the Business Income Tax Act such as business income and deductible cost.

Separation of the direct investment shares and portfolio shares create the baseline in the future development as well as identification of substantial shareholdings and business relationship. Subject (selling company) requirements could be simplified so that the subject company is a legal person.

Object (the target company to be sold) requirement could include at least two options:

- As the first option, the requirement could be that the object company is a subsidiary company, which means that the owner company owns the certain percentage of the equity and the equity is divided into shares (based on the Dutch feature).

- As the second option, the ownership share should be 10 percent or more, which ensures that the object of the alienation is business-related (based on the Danish feature).

Less than 50 percent of the total assets of the object company should be passive, which ensures that the object of the alienation is business-related. The meaning of the passive assets could be defined more accurately than in the Netherlands to avoid interpretation issues. In addition to these requirements, the future corporate capital gains taxation model should refer to the definition of business income.

More attention should be still put in the future studies for the corporate capital gains taxation from the perspective of an effective and neutral group and double taxation. More focus should also be given on the taxation topics from the viewpoint of the economic growth and business innovation. The viewpoint of the group could be investigated further and the future corporate capital gains tax model drafted above could then be compared to the flow-through approach, in which the focus is rather on the terms of holding company and subject company instead of the simple and clear corporate capital gains tax model.

\section{References}

Ault, Hugh J. and Brian J. Arnold (principal authors). 2004. Comparative income taxation: a structural analysis. 2nd edition. The Hague: Kluwer Law International.

Avi-Yonah, Reuven S. 2016. "Tax Notes.” Proposals for International Tax Reform: Is There a Middle Road? 153 (9): 1169-76.

Bankman, Joseph, Thomas D. Griffith and Katherine Pratt. 2005. Federal Income Tax. Examples and Explanations. Fourth Edition. New York, United States of America: Aspen Publishers.

Bittker, Boris I. 1981. Federal taxation of income, estates and gifts. Volume 1-4. Boston: Warren, Gorham \& Lamont.

Blum, Walter. 1957. "Taxes." A handy summary of the capital gains arguments. Vol. 35. No. 4. Pages 247-266.

Brooks, Michael and John Head. 1997. Tax avoidance: in economics, law and public. In the publication: Tax avoidance and the rule of law. Amsterdam: IBFD Publications. Pages 53-91. 
Cahiers de droit fiscal international 2007. Vol. 92a. Rotterdam: International Fiscal Association.

Cahiers de droit fiscal international 2009. Vol. 94b. Rotterdam: International Fiscal Association.

Chorvat, Terrence R. 2003. "Connecticut Law Review." Perception and income: the behavioral economics of the realization doctrine. Pages 75-124.

Chorvat, Terrence R. 2007. "Virginia Tax Review.” Tax shelters, Dutch books, and the fundamental theorem of asset pricing. Pages 859878.

Cunningham, Noël B. and Deborah H. Schenk. 1993. "Tax Law Review." The case for a capital gains preference. Pages 319-380.

Davidson, David. 1889. Om beskattningsnormen vid inkomstskatten. Uppsala.

De Mooij, Ruud A. and Micheal P. Devereux. 2008. Alternative Systems of Business Tax in Europe. An applied analysis of ACE and CBIT Reforms. Oxford: Oxford Centre for Business Taxation. http://ec.europa.eu/taxation_customs/resources/documents/com mon/publications/studies/acecbit_study.pdf

Eggert, W. and B. Genser. 2005. Dual income taxation in EU member countries. CESifo DICE. Report 3 (1).

Eicke, Rolf. 2009. “EUCOTAX series on European taxation.” Tax planning with holding companies - repatriation of US profits from Europe. Concepts, strategies, structures. Vol. 22. Alphen aan den Rijn: Kluwer Law International.

Evans, Chris and Cedric Sandford. 1999. "British Tax Review." Capital gains tax - an unprincipled tax? Pages 387-405.

Evans, Thomas L. 1992. "Taxes." The realization doctrine after cottage savings. Vol. 70. December. Pages 897-911.

Gjems-Onstad, Ole and Benn Folkvord eds. 2013. Aktuell bedriftsbeskatning. 1. utgave. Oslo: Gyldendal Juridisk.

Goldberg, William J. and Mark T. Watson. 1996. "Journal of financial planning." Short sales against the bow: endangered income tax planning technique. Pages 62-67.

Gravelle, Jane G. 1994. The economic effects of taxing capital income. Cambridge Massachusetts; London: MIT Press

Guerin, Sanford M. 1985. “Arizona State Journal.” Capital gain and tax loss policy - economic substance or legalistic form? Pages 905933.

Halperin, Daniel 1998. "Ohio Northern University Law Review." Saving the income tax: an agenda for reasearch. Pages 493-515.

Harberger, Arnold C. and Martin J. Bailey eds. 1969. The Taxation of income from capital. Studies of government finance. Washington: Brookings Institution.

Harris, Peter A. 1996. Corporate/Shareholder Income Taxation and Allocating Taxing Rights between Countries. A Comparison of Imputation Systems. Netherlands: IBFD Publications.

Harris, Peter. 2013. Corporate tax law. Structure, policy and practice. New York: Cambridge University Press.

Hasen, David M. 2004. "Tax Law Review." A realization-based approach to the taxation of financial instruments. Vol. 57, spring. Pages 397-481.

Helminen, Marjaana. 1999. The dividend concept in international tax law: dividend payments between corporate entities. Dissertation thesis. Series on international taxation; no 25. London: Kluwer Law International.

Helminen, Marjaana. 2000. "EC Tax Review." Dividend equivalent benefits and the concept of profit distribution of the EC ParentSubsidiary Directive. Volume 9. Issue 3. Deventer: Kluwer Law and Taxation Publishers.
Helminen, Marjaana. 2013. EU tax law - direct taxation. 3rd edition. Amsterdam: IBFD.

Hicks, J. R. 1946. Value and capital: an inquiry into some fundamental principles of economic theory. (Second edition, reprinted 1968). Oxford: Clarendon Press.

Hjerppe, Reino and Seppo Kari and Jaakko Kiander eds. 2006. Kasvumallin muutos ja veropolitiikan haasteet. VATT-julkaisuja 44. Helsinki: Valtion taloudellinen tutkimuskeskus.

Hjerppe, Reino, Seppo Kari, and Henri Lönnqvist, eds. 2001. Verokilpailu ja verotuksen kehittämistarpeet. VATT-keskustelualoitteita 261. Helsinki: Valtion taloudellinen tutkimuskeskus.

Hjerppe, Reino, Kari Seppo, Jaakko Kiander, and Panu Poutvaara, eds. 2003. Verokilpailu ja Suomen verojärjestelmä. Porvoo: WSOY.

Holmes, Kevin. 2001. The concept of income - A multi-disciplinary analysis. Vol. 1. Amsterdam: IBFD Doctoral Series.

Holmes, Kevin 2005. Deferral possibilities. In the publication: Essers, Peter and Arie Rijkers eds. The notion of income from capital. EATLP International Tax Series. Volume 1. Amsterdam: IBFD. Pages 147-181.

Institute for Fiscal Studies. 1978. "The structure and reform of direct taxation: Report of a committee chaired by Professor J. E. Meade." London: Institute for Fiscal Studies.

Kari, Seppo. 2015. "Nordic Tax Journal." Corporate tax in an international environment - Problems and possible remedies. Volume 1. Pages 1-16.

Kavelaars, Peter. 2005. Accrual versus realization; in the notion of income from capital. Amsterdam: IBFD.

Keskitalo, Wisa M. Sääski. 2012. Osakeyhtiön verovapaat osakeluovutukset. Dissertation. Suomalainen lakimiesyhdistys.

Knuutinen, Reijo. 2009. Muoto ja sisältö vero-oikeudessa - erityistarkastelussa rahoitus- ja sijoitusinstrumentit. Helsinki: Suomalainen lakimiesyhdistys.

Kornhauser, Marjorie E. 1985. " Southwestern Law Journal." The origins of capital gains taxation: what's law got to do with it? Pages 869-928.

Kukkonen, Matti. 1992. Lukitusvaikutus ja efektiivinen veroaste pääomavoittoverotuksessa. Helsingin kauppakorkeakoulun julkaisuja. B, ISSN 0356-889X; 124. Helsinki: Helsingin kauppakorkeakoulu.

Kukkonen, Matti. 1994. Osakeyhtiön myynnin verotus: tutkimus osakeyhtiön myynnin tuloverotuksesta erityisesti harvainomisteista yhtiötä silmällä pitäen. Dissertation. Helsinki: Lakimiesliiton kustannus.

Kukkonen, Matti. 2000. Capital gains taxation and realization behaviour: evidence from Finnish panel data. Acta Universitatis oeconomicae Helsingiensis A 168. Helsinki: Helsinki School of Economics and Business Administration.

Kukkonen, Matti and Risto Walden. 2015. Elinkeinoverolaki käytännössä. 3. uudistettu painos. Helsinki: Talentum Pro.

Land, Stephen B. 1996. "Tax Law Review." Defeating deferral: a proposal for retrospective taxation. Pages 45-117.

Lang, Michael and Pasquale Pistone and Josef Schuh and Claus Staringer, eds. 2013. Introduction to European tax law: direct taxation. 3rd edition. Wien: Linde.

Lang, Michael and Pasquale Pistone and Josef Schuh and Claus Staringer and Alfred Storck, eds. 2013. Corporate income taxation in Europe: the common consolidated corporate tax base (CCCTB) and third countries. Cheltenham, UK: Edward Elgar.

Laukkanen, Antti. 2007. Taxation of investment derivatives. Doctoral series IBFD; vol. 13. Amsterdam: IBFD - Academic Council. 
Melz, Peter. 1986. Kapitalvinst beskattningens problem företrädesvis vid fastighetsförsäljningar. Juridiska Fakulteten i Stockholm.

Mirza, Abbas Ali and Graham J. Holt. 2011. IFRS: Practical Implementation Guide and Workbook. Hoboken, New Jersey: John Wiley \& Sons, Inc.

Myrsky, Matti 2014. "Verotus." Uutta kirjallisuutta. Arvio teoksesta Yritysverotus - EU-tuomioistuimen ratkaisut ja niiden tulkinta. 1/2014, ISSN 0357-2331. Pages 90-97.

OECD. 2006. "Taxation of capital gains of individuals: policy considerations and approaches." OECD tax policy studies no. 14. Paris: OECD.

Paul, Deborah L. 1996. “Florida Tax Review.” Another uneasy compromise: the treatment of hedging in a realization income tax. Pages 1-50.

Pechman, Joseph A. 1987. Federal tax policy. 5th edition. Washington D.C.: The Brooking Institution.

Poterba, James M. 1987. “Journal of Public Economics.” How burdensome are capital gains taxes? Pages 157-172.

Potter, Clarissa. 1999. "Valparaiso University Law Review." Mark-tomarket taxation as the way to save the income tax - a former administrators view. Pages 879-905.

Powell, Thomas Reed 1922. "Harvard Law Review." Income from corporate dividends. Pages 363-392.

Rosenberg, Joshua D. 1988. "Michigan Law Review." Tax avoidance and income measurement. Pages 366-497.

Seltzer, Lawrence H. 1951. The nature and tax treatment of capital gains and losses. New York: National Bureau of Economic Research.
Schenk, Deborah H. 2004. “Tax Law Review.” A positive account of the realization rule. Vol. 57, spring. Pages 355-396. (Schenk 2004a)

Schenk, Deborah H. 2004. "Tax Law Review." An efficiency approach to reforming a realization-based tax. Vol. 57, summer. Pages 503547. (Schenk 2004b)

Shaviro, Daniel N. 1992. "Tax Law Review." An efficiency analysis of realization and recognition rules under the federal income tax. Pages 1-68.

Shuldiner, Reed 1993. "Tax Law Review.” Indexing the tax code. Pages 537-659.

Simons, Henry C. 1955. Personal income taxation: the definition of income as a problem of fiscal policy. 3. impr. The University of Chicago Press.

Simontacchi, Stefano. 2007. Taxation of capital gains under the OECD Model Convention: with special regard to immovable property. Alphen aan den Rijn: Kluwer Law International.

Staveley, Ben. 2005. "British Tax Review." The quest for the allowable loss: reflections on Lord Hoffmann's approach to Ramsay. Pages 609-619.

Torkkeli, Anu. 2016. Structuring Corporate Capital Gains Tax System in the European Union - A Comparative Finnish Perspective. Dissertation. Publications of Hanken School of Economics, Nr 296, Helsinki 2016.

Weisbach, David A. 1997. "National Tax Journal." Should a short sale against the box be a realization event? Pages 495-506.

Weisbach, David A. 1999. “Tax Law Review. “ A partial mark-to-market system. Vol. 53, fall. Pages 95-135. 